\title{
KOSMOLOGI RUANG VERTIKAL DAN HORIZONTAL PADA RUMAH TRADISIONAL (SA'O) DESA ADAT SAGA, KABUPATEN ENDE, FLORES
}

\author{
Zulkifli H. Achmad ${ }^{1}$, Antariksa ${ }^{2}$, Agung Murti Nugroho ${ }^{3}$
}

1. Mahasiswa Program Magister Arsitektur Lingkungan Binaan, Universitas Brawijaya;

2. Dosen Program Magister Arsitektur Lingkungan Binaan, Universitas Brawijaya;

3. Dosen Magister Arsitektur Lingkungan Binaan, Universitas Brawijaya

Email: zularch14@gmail.com,mr.antariksa@gmail.com, sasimurti@yahoo.co.id

\begin{abstract}
Abstrak
Kosmologi adalah ilmu yang berkaitan dengan kemestaan (cosmos) dalam sebuah konsep hubungan antara dunia manusia (micro-cosmos) dan jagad raya. Ruang dalam rumah tradisional Saga memiliki nilai-nilai dan ke-khasan yang menarik dikaji secara arsitektural. Pengaruh kepercayaan Du'a Ngga'e terhadap bentuk dan ruang rumah tradisional Saga menarik diidentifikasi secara arsitektural. Penelitian ini menggunakan metode kualitatif dengan pendekatan etnografi yang bersifat deskripsi. Temuan penelitian ini adalah tentang kosmologi ruang pada rumah tradisional. Pandangan kosmologi ruang pada rumah tradisional Saga dibedakan menjadi tiga bagian yaitu adalah lewu, one dan gara sebagaimana menyebut posisi bagian tubuh manusia. Pandangan kosmologi ruang pada rumah tradisional $\left(\mathrm{Sa}^{\prime} \mathrm{o}\right)$ Desa Adat Saga secara horizontal dilukiskan dengan ibu terbaring. Hakekat rumah tradisional Saga merupakan inti dari kesuburan dan kelahiran. Sosok seorang seorang ibu terlihat jelas pada ukiran pintu (pene ria) masuk $S a$ 'o yakini ukiran payudara seorang wanita yang melambangkan kehidupan manusia dan sebuah papan yang melintang dibawah peneria yaitu koba leke yang melambangkan perkembangan manusia. Posisi kepala ibu di bagian lulu (ruang istirahat laki-laki), kedua kaki yang telentang kedepan berada pada bagian tenda (ruang istirahat atau menerima tamu), kedua tangan yang mereba berada pada ruang dhembi kanan dan kiri, rahim atau puse berada pada ruang koja ndawa.
\end{abstract}

Kata kunci: rumah tradisional ( $s a^{\prime} o$ ), desa adat saga, kosmologi ruang vertikal dan horizontal

\begin{abstract}
Title: Vertical and Horizontal Room Cosmology in Traditional House (Sa'o) Adat Saga Village, Ende Regency, Flores

Cosmology is the science related to kemestaan (cosmos) in a concept of the relationship between the human world (micro-cosmos) and of the universe. Space in traditional house Saga has values and khasan interesting architecturally is examined. The influence of Ngga'e on the Du'a belief and traditional home space Saga interesting architecturally is identified. This study uses qualitative methods with an ethnographic approach that is description. The findings of this study is about the cosmology of the space on a traditional home. Cosmological view of space in traditional house Saga is distinguished into three parts namely is lewu, gara as one and mention the position of the human body parts. Cosmological view of space in traditional Indigenous Villages (Sa'o) Saga depicted horizontally with the mother lay. Nature of traditional house Saga is the core of fertility and birth. Being a mother is clearly visible on a carved door (pene ria) enter Sa'o believe carving the breasts of a woman who symbolizes the human life and a transverse under IE peneria koba leke symbolizing the human
\end{abstract}


development. The position of the head of the mother at the lulu (the dugout), second legs on his back is to the fore in the tent (dugout or accepting guests), second hand mereba is at the right and left dhembi space, the womb or humanitarian space are at puse ndawa.

Keywords: traditional house (sa'o), the indigenous village of saga, the cosmology of the vertical and horizontal spaces

\section{Pendahuluan}

Kosmologi merupakan pengetahuan yang meneliti asal usul, struktur, hubungan ruang-waktu dalam alam semesta (Kustedja,et.al, 2012). Kosmologi berada pada level tertinggi (mentifact-Pangarsa, 2008) yang menentukan ideologi dan pandangan hidup manusia, serta pengambilan keputusan-keputusan desain (Titisari, 2016).

Ilmu kosmos berkaitan dengan pertanyaan-pertanyaan: bagaimana bumi (dan dunia) diciptakan, kapan, bagaimana kedudukan bumi dan bendabenda langit, bagaimana sistem yang mengaturnya, bagaimana pengaruh dan hubungan satu dengan yang lain, dan sebagainya. Nelson et.al, mengatakan kosmologi di level empiric diwujudkan salah satunya dalam bentuk kelender suku-suku kuno Amerika yang menentukan waktu dan ruang bagi kegiatan mereka (Nelson et.al dalam Titisari, 2016).

Norma-norma agamalah yang mendasari adanya bentuk-bentuk demi mendapatkan keselamatan, dan juga bentuk rasa syukur terhadap Tuhan, khususnya bagi keluarga berkaitan (Mangunwijaya, 1988). Alam pemikiran tradisional digambarkan alam sebagai suatu sistem yang beraturan (Kustedja, et.al, 2012).

Salah satu dari hasil kebudayaan sebagai upaya manusia dalam bersahabat dengan alam tempat hidupnya adalah lingkungan arsitektur. Arsitektur sebagai ciptaan manusia dianggap perlu berkontekstualisasi dengan fenomena alam tersebut. YB. Mangunwijaya dalam bukunya Wastu Citra (1988), pada masamasa dahulu, masyarakatnya telah membagi dunia dalam tiga lapis, dunia atas (surga, kahyangan), dunia bawah (dunia maut) dan dunia tengah (dunia yang didiami oleh manusia). Arsitektur dapat dipandang sebagai manifestasi dari aspek sosial, budaya, teknik, ritual, dan mampu mengekpresikan keyakinan atau kaidah-kaidah yang bersifat kosmologis, serta mampu mengkomunikasikan informasi yang mengandung system nilai (Rapoprt dalam Mashuri, 2012).

Bagi masyarakat Ende-Lio, rumah tidak hanya berfungsi praktis sebagai tempat tinggal melainkan mengungkapkan simbol-simbol kosmologis. Rumah tradisional ( $\mathrm{Sa}$ 'o) terkandung wujud kepercayaan dan ikatan antara yang ilahi dengan insani, keharmonisan hidup masyarakat, kepercayaan terhadap nenek moyang serta sejarah-sejarah asal-usul masyarakat setempat.

Konsep tradisional Ende-Lio, sebuah rumah tradisional hanya memiliki dimensi fungsional sebagai tempat hunian, tetapi juga sekaligus melalui unsur-unsur bentuk tertentu menampilkan pandangan kosmologis dan fiosofis yang mendalam. Lebih jauh lagi rumah dianggap sebagai simbol dari jagad raya/kosmos, dimana hirarki kosmos ditampilkan pada zona vertikal dan horizontal. 
Desa Adat Saga merupakan salah satu desa tradisional wilayah permukiman arsitektur tradisional Ende-Lio. Desa Adat Saga masih memegang nilai-nilai kebudayaan terdahulu serta kepercayaan-kepercayaan dari nenek moyang. Desa Adat Saga memiliki potensi yang besar sebagai desa yang masih mempertahankan kebudayaan daerah sampai sekarang dengan adanya kegiatan-kegiatan upacara adat yang dilakukan hampir sepanjang tahun yang dimulai dari upacara adat panen raya yang biasa disebut pesta Nggua yang biasa dilakukan pada bulan September. (hasil wawancara bapak Maximus Wolo, (April, 2016).

Rumah tradisional pada Desa Adat Saga juga disebut $\mathrm{Sa}$ 'o yang mempunyai peranan yang sangat penting, karena berhubungan langsung dengan kepercayaan Du'a Ngga'e terutama pada pesta-pesta adat pada rumah tradisional ( $\left.\mathrm{Sa}{ }^{\prime} \mathrm{o}\right)$. Rumah tradisional ( $\mathrm{Sa} \mathrm{o}^{\prime}$ ) pada saat sekarang, sudah jarang ditempati sebagai wadah hunian oleh pemiliknya, tetapi lebih sering digunakan untuk kebutuhan yang bersifat publik seperti kegiatan-kegiatan upacara adat dan tempat upacara religi bagi masyarakat secara umum maupun rumpun keluarga. Masyarakat Saga percaya segala sesuatu dalam dunia mempunyai nyawa, termasuk manusia yang sudah meninggal masih dianggap tetap hidup.

Orang Saga mengenal dunia menjadi tiga bagian atau tiga lapis yaitu dunia atas, dunia tengah, dan dunia bawah. Dunia atas disimbolkan sebagai surga atau dunia yang paling tinggi, dunia tengah tempat untuk bernaung, dan aktivitas dan dunia bawah merupakan dunia maut atau dunia kotor. Rumah dianggap sebagai penjelmaan dari bentuk makrokosmos (alam raya), yaitu dunia atas, tengah, dan dunia bawah (Moerdjoko dalam Mashuri, 2012). Sistem vertikal sering dikaitkan dengan nilai ketuhanan pada sumbu vertikal, dan sistem horizontal lebih mengandung nilai kemanusiaan yang mengarah hubungan sosial antara manusia (Pangarsa, 2006).

Arsitektur tradisional di Indonesia mengatakan ciri yang menonjol adalah adanya unsur horizontal dan vertikal terbentuk oleh kolom dan balok, lambang dari integritas manusia dan alam. kedua unsur dan bahan-bahan lainnya langsung diambil dari alam dengan proses sederhana juga menjadi ciri penting dari arsitektur tradisional di Indonesia. Berdasarkan latar belakang maka rumusan masalah adalah bagaimana konsep kosmologi ruang vertikal dan horizontal pada rumah tradisional ( $\mathrm{Sa}$ 'o) Desa Adat Saga, Kabupaten Ende, Flores.

\section{Metode}

Metode yang digunakan dalam penelitian ini adalah pendekatan etnografi yang bersifat deskripsi. Metode penelitian merupakan penelitian yang mempelajari masalah kultural, menyajikan cara pandang kehidupan di dalam objek (Spradley, 1997). Metode ini di fokuskan pada konsep ruang vertikal dan horizontal.

Dalam pengumpulan data, peneliti ikut berperan dalam kegiatan (participant observation) yang diteliti, peneliti masuk kedalam dan membiarkan setting alamiah terjadi didalam (Basrowi \& Suwandi, 2008).

Sumber data berasal dari infoman kunci (key informan) yaitu tokoh masyarakat setempat atau ketua adat (mosalaki) 
yang terdiri dari 10 mosalaki yang menjadi nara sumber dan data-data sekunder berupa buku, jurnal atau sumber data lain yang telah ada.

\section{Hasil dan Pembahasan}

\section{Gambaran Lokasi}

Desa Adat Saga merupakan sebuah wilayah permukiman adat di Kabupaten Ende. Desa merupakan bagian dari permukiman Suku Ende-Lio dari sekian banyak permukiman adat Desa Adat Saga yang luasnya $11.06 \mathrm{~km}^{2}$ dengan 5 ,
$73 \%$ dari seluruh desa terletak di Kecamatan Detusoko, Kabupaten Ende. Letak desa adat cukup dekat dengan ibukota kecamatan, yaitu sekitar $13 \mathrm{~km}$ dari ibu kota kecamatan Detusoko dan sekitar $25 \mathrm{~km}$ dari pusat ibukota kabupaten yakni, Kota Ende. Lingkungan fisik Desa Adat Saga berbukit-bukit, yang dikelilingi pohonpohon yang rindang. Desa Adat Saga terdiri dari 3 dusun/lingkungan 4 rukun warga (RW) dan 9 rukun tetangga (RT) dengan jumlah penduduk 668 jiwa dengan kepadatan penduduk 60 orang/Km (BPS Kabupaten Ende 2015).

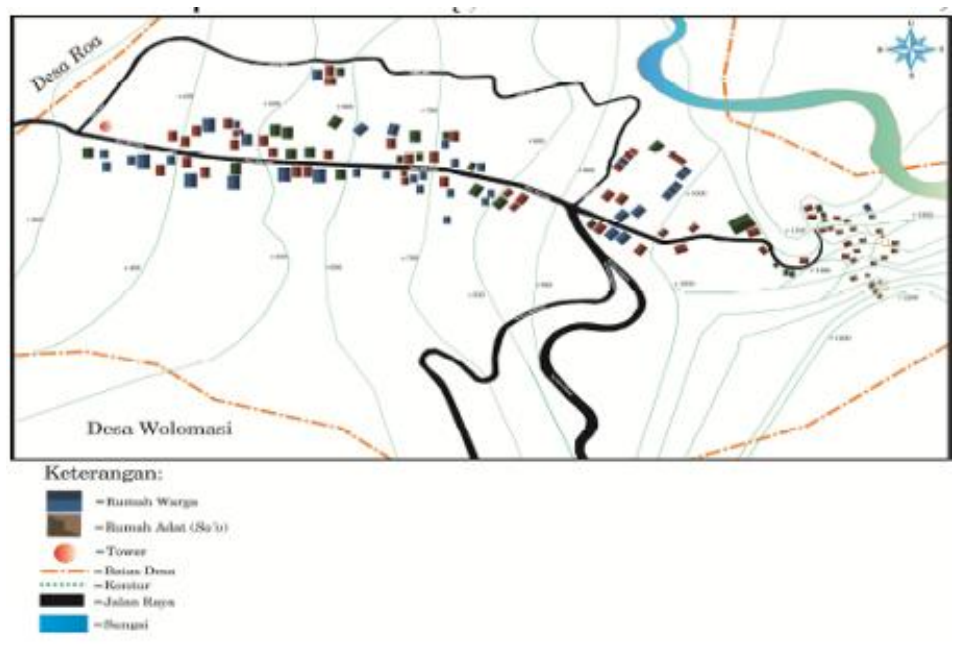

Gambar 1. Permukiman desa adat Saga

Sumber: Hasil Analisis, 2016

Sejarah Terbentuknya Permukiman Desa Adat Saga

Secara etimologi, Saga terdiri dari dua kata yaitu $S a$ dan $G a$. $S a$ yang artinya bunyi air atau suara dan $G a$ artinya terpandang. Jadi secara harfiah Saga memiliki arti memiliki arti suara yang berwibawa, suara terpandang atau suara terhormat, dapat juga diartikan bunyi air yang mengalir kurang deras atau keras tetapi menghanyutkan, atau juga dikatakan suara kesejukan atau suara perdamaian dan suara keberuntungan. Pengertian diatas dikatakan sejak dulu hingga saat secara implisit terdapat waka atau martabat kepemimpinan yang telah diwariskan oleh nenek moyang.

Terbentuknya permukiman Desa Adat Saga berawal dari perkampungan yang berada di bagian barat perkampungan yang sekarang yaitu Mboto. Di Mboto sendiri dibagi dua tempat yaitu Mboto Wena yang ditempati oleh embu Wolo 
dan di Mboto Wawo ditempati oleh embu Limbu. Kedua embu membangun perkampungan secara bersama-sama di Mboto. Wilayah permukiman adat Saga, sendiri sudah ada orang yang mendiami yaitu Dala Wolo. Pada saat itu Dala Wolo menempati bersama adiknya Labha Dile dengan membangun awal perkampungan Saga pada saat itu. Kedua kakak beradik membangun rumah tradisional ( $\mathrm{Sa}$ 'o) yaitu Sa'o Nggua.

Pada awalnya kedua kakak beradik yaitu Dala Wolo dan Lele Mbele tinggal dalam satu rumah tradisional di Sa'o Nggua Dala Wolo namun karena semakin banyaknya jumlah keluarga sehingga Lele Mbele membangun rumah tradisional ( $\mathrm{Sa}$ 'o) sendiri dengan nama yang sama yaitu Sa'o Nggua Lele Mbele, kemudian diikuti oleh eja kera mereka yaitu Tola Ndale dengan rumah ( $\mathrm{Sa}$ 'o) yaitu Sa'o Ria Tola Ndale. Pada saat itu sudah terdapat keda dan tubu musu yang dibangun oleh Dala Wolo di depan rumah tradisional untuk melakukan seremonial adat atau kegiatan upacara lainnya. Keda yang dibangun oleh Dala Wolo fungsinya berubah.

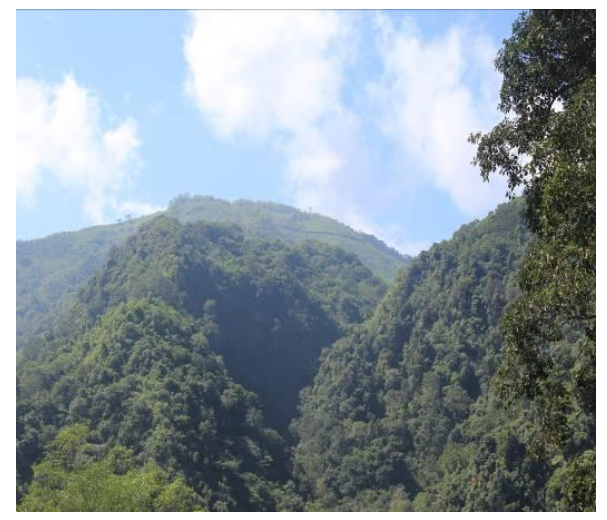

Gambar 2. Mboto

Sumber: Dokumentasi Pribadi, 2016

Setelah ketiga orang yang mendiami dipermukiman adat Saga, maka antara kedua embu (embu wolo dan limbu) melakukan perjanjian antara nenek moyang yang disebut Nggo Nggoro Ngamba Kara. Perjanjian menyatakan semua masyarakat yang di hidup di Mboto baik dari embu wolo dan embu limbu pindah ke permukiman Desa Adat Saga dan membangun bersama-sama permukiman. Oleh karena itu masyarakat bergotong-royong membangun bersama-sama perkampungan dan mendiami secara bersama-sama sampai sekarang.

Sebelum terjadi gempa tahun 1992, kampung adat sangat ramai, semua masyarakat berkumpul dan menempati masing-masing rumah tradisional ( $\mathrm{Sa}$ 'o) yang telah ada berdasarkan keturunan mereka. Setiap rumah tradisional ( $\mathrm{Sa}$ 'o) ditempati/ ditinggali oleh seorang mosalaki (ketua adat) yang bertugas menjaga dan mengawasi semua keluarga pada rumah tradisional ( $\mathrm{Sa}$ 'o). Setelah terjadi gempa 1992 , beberapa rumah tradisional ( $\mathrm{Sa}$ 'o) rusak berat ada pula rumah tradisional (Sa'o) yang miring," kata Maximus Wollo", salah satu keturunan mosalaki (ketua adat) Desa Adat Saga.

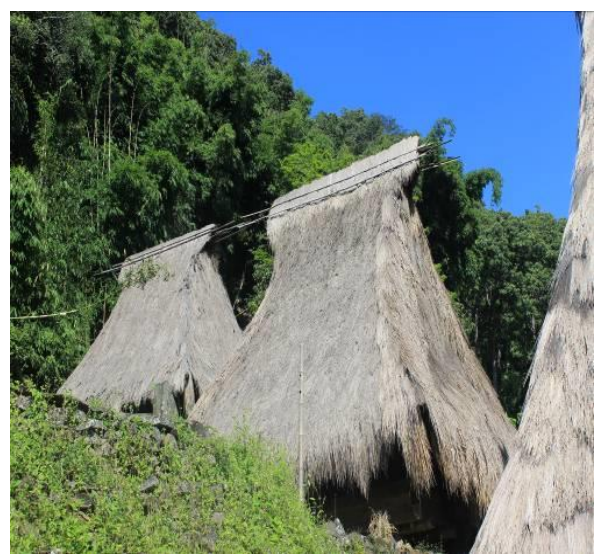

Gambar 3. Rumah tradisional (sa'o) desa adat Saga

Sumber: Dokumentasi Pribadi, 2016 
Adat dan Kepercayaan Desa Adat Saga

Adat adalah aturan-aturan tentang kehidupan manusia yang disepakati dalam suatu penduduk dalam suatu daerah tertentu untuk mengatur tingkah laku anggota masyarakatnya sebagai kelompok sosial (Mashuri, 2012). Adat telah melembaga dalam kehidupan masyarakat baik berupa tradisi, adat istiadat, upacara, dan sebagainya, yang mampu mengendalikan perilaku masyarakat dalam wujud perasaan senang atau bangga, dan peranan tokoh adat. Kepercayaan erat hubungannya dengan upacara-upacara religius, dan menentukan tata ukur dari pada unsurunsur acara serta rangkaian alat-alat yang dipakai dalam upacara itu (Koenjaraningrat, 1974).

Orang Ende-Lio pada masyarakat Desa Adat Saga percaya segala sesuatu didunia mempunyai nyawa. Nyawa manusia tetap hidup walaupun sudah meninggal. Bagi masyarakat Saga percaya para leluhur yang sudah meninggal merupakan perantara mereka antara dunia nyata dengan alam semesta. Masyarakat Desa Adat Saga secara umum memeluk agama Kristen Katolik, tetapi mereka tetap memega ng kepercayaan-kepercayaan terdahulu (BPS Kabupaten Ende, 2015). Sebelum masuknya agama-agama besar dengan paham monoteisme, masyarakat Saga pada dasarnya telah memiliki kepercayaan yang diwariskan secara lisan turun temurun. Kepercayaan diwujudkan dengan istilah wujud tertinggi keilahian yang disebut $D u^{\prime} a$ Ngga'e (Mbete et.al, 2004).

Du'a Ngga'e menurut konsep kepercayaan masyarakat Saga merupakan wujud tertinggi. Pengertian
$D u^{\prime} a$ hadir sebagai yang sulung artinya yang paling awal hadir dari segalanya termasuk manusia. Kata $D u^{\prime} a$ bahkan telah ada sebelum bumi tercipta. Kata $D u^{\prime} a \quad$ selalu berarti, 'sulung', 'terdahulu', 'tertua', 'berdaulat', 'berpribadi tertinggi', sedangkan konsep Ngga'e mengandung makna 'keagungan', penuh dengan daya, kebijaksanaan, kekuatan, kekayaan. Ungkapan tentang keagungan dan kebesaran Du'a Ngga'e tersurat pada $D u^{\prime} a$

Gheta Lulu Wula, Ngga'e Ghale Wena Tana yang secara harafia diartikan $D u^{\prime} a$ yang berkuasa di ujung bulan, dan Ngga'e yang menguasai dasar bumi yang paling dalam. Pemujaan kepada Du'a Ngga'e diungkapkan dalam bentuk upacara adat-upacara ritual dengan berbagai sesajen, persembahan atau korban. Sesajen bermacam-macam bentuk, tempat dan arahnya disesuaikan dengan upacara yang dilaksanakan. Persembahan kepada Du'a Ngga'e menggunakan Babi atau Ayam. Adanya kepercayaan terhadap Du'a Ngga'e terkait dengan pandangan masyarakat Desa Adat Saga terhadap tata ruang jaga raya atau makro kosmos yang dipandang tiga unsur yaitu dunia atas (tempat yang paling tinggi dan bersemayamnya para leluhur yang sudah meninggal, dunia tengah (tempat bertemunya masyarakat dan dunia kehidupan manusia) dan dunia bawah (tempat memilihara hewan/ dunia kotor). Penggambaran dari tiga unsur digambarkan berdasarkan postur tubuh manusia dengan manusia itu sendiri sebagai pusatnya (Tuan dalam Haryanto et.al, 2012). 


\section{Rumah Tradisional Desa Adat Saga}

Rumah tradisional masyarakat Desa Adat Saga disebut $\mathrm{Sa}$ 'o. Jumlah $\mathrm{Sa}$ 'o di Desa Adat Saga sekitar 20 Sa'o. Setiap Sa'o terdapat mosalaki (ketua adat). Rumah tradisional ( $\mathrm{Sa}$ 'o) dalam masyarakat Saga bukan sekedar untuk tinggal, tetapi juga menggambarkan fungsi-fungsi sosial tertentu sehingga hampir setiap rumah tradisional mempunyai namanya yang berbedabeda.

Bentuk rumah tradisional ( $\mathrm{Sa}$ 'o) ialah persegi empat dengan atap yang menjulang tinggi sebagai simbol kesatuan dengan sang ilahi. Dipuncak atap terdapat 3 simbol yaitu kola keda, kolo Sa'o dan saga wula leja (kepala keda, kepala $\mathrm{Sa}$ 'o dan tiang altar matahari dan bulan). Berdasarkan kepercayaan masyarakat Saga yang membagi dunia menjadi tiga yaitu dunia atas, dunia tengah dan dunia bawah sehingga penggambaran rumah tradisional ( $\mathrm{Sa}$ 'o) menyerupai bentuk manusia yaitu atap (dunia atas), dunia tengah (badan rumah) dan dunia bawah (kaki rumah).

Secara hirarkis vertikal rumah tradisional Saga dibedakan menjadi tiga bagian yaitu adalah lewu, one dan gara sebagaimana menyebut posisi bagian tubuh manusia. Gara adalah kepala, one merupakan badan dan lewu adalah kaki. Apabila menyebut ruang atap, dinding dan tiang lantai panggung, maka ruang atap sebagai gara, dinding sebagai one dan kolong disebut lewu. Bagian kaki (kolong) disebut lewu Sa'o, yaitu kolong rumah tradisional yang terbentuk oleh hubungan antara tiang-tiang yang disebut leke. Bagian berfungsi sebagai tempat mengurung hewan seperti Babi dan Ayam dan mempunyai fungsi religius. Tiang-tiang pada struktur $\mathrm{Sa} o$ menggunakan batu yang sudah dilancipkan menentukan patokan dari tiang-tiang terdapat sebuah batu yang disebut watu nitu. Watu nitu merupakan sebuah batu yang sudah ada sejak zaman nenek moyang (hasil wawancara Welhemus Sowa yang merupakan arsitek dari rumah tradisional ( $\mathrm{Sa}$ 'o). Bagian badan $\mathrm{Sa}^{\prime} \mathrm{o}$ disebut one, yang terdiri dari atas ruang-ruang yang dinamakan berdasarkan fungsi dan perannya. Ruang bagian depan disebut tenda berfungsi sebagai ruang santai, ruang dhembi merupakan ruang istirahat perempuan, ruang lulu merupakan ruang istirahat laki-laki sedangkan ruang tengah disebut koja ndawa yang merupakan pusat dari ruang-ruang ada Sa'o. Ruang koja ndawa juga disebut rahim, karena ruang digunakan sebagai tempat melakukan upacara adat, tempat berkumpul, tempat musyawarah keluarga. Bagian atas disebut dengan gara. Bagian atas merupakan bagian yang paling sakral dalam rumah karena dianggap roh-roh nenek moyang atau leluhur mereka bersemayam. Pada rumah tradisional ( $\mathrm{Sa}$ 'o) tersusun 5 lapisan (5 gara) jika semakin keatas posisi gara semakin sakral ruang. Posisi dari gara dibiarkan terbuka dengan dari bawah sampai atap. Posisi terbuka menurut kepercayaan masyarakat Saga agar mereka lebih dekat dengan Du'a Ngga'e dan leluhur. 


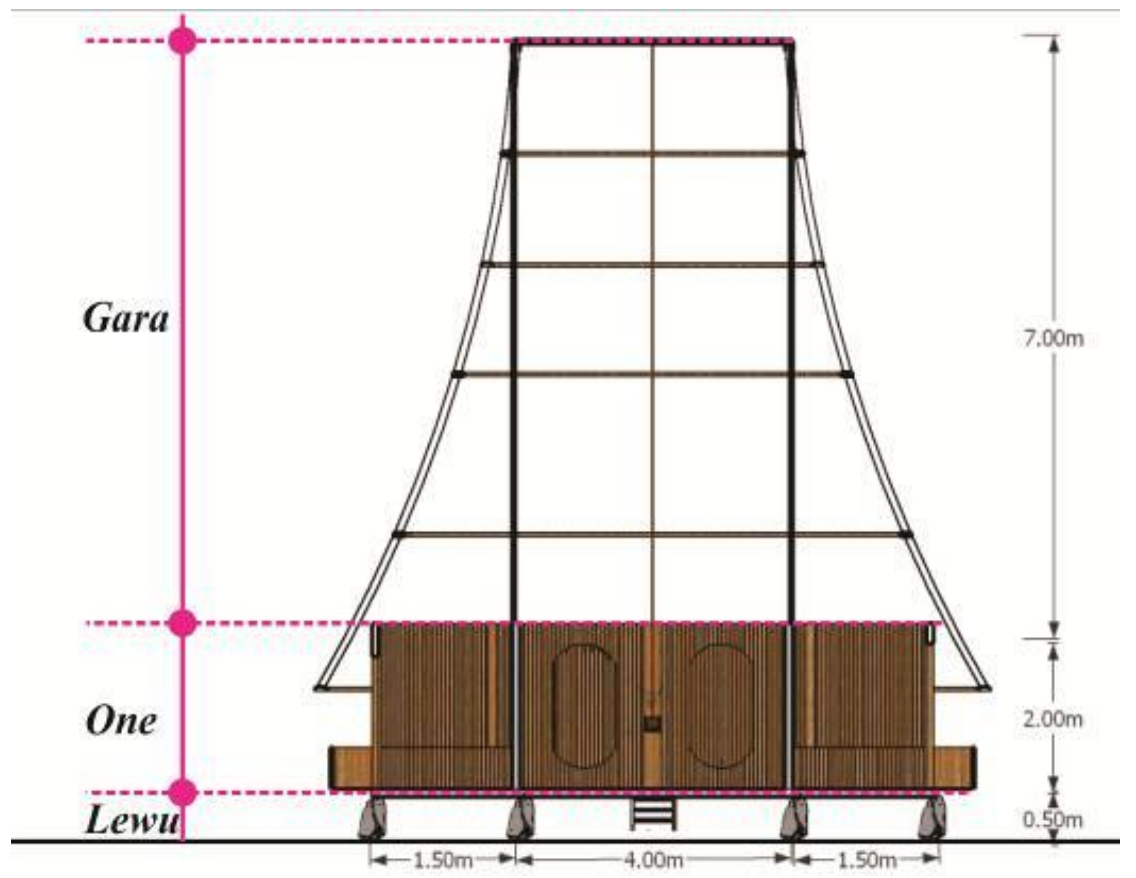

Gambar 4. Pembagian sistem vertikal pada rumah tradisional ( $s a^{\prime}$ 'o) desa adat Saga Sumber: Hasil Analisis, 2016

\begin{tabular}{|c|c|c|c|}
\hline Sa'o & $\begin{array}{c}\text { Bagian } \\
\text { Struktur }\end{array}$ & Fungsi & Konotasi/Simbolik \\
\hline Bagian Atas & Gara & $\begin{array}{lr}\text { Penutup } & \text { seluruh } \\
\text { struktur } & \text { rumah } \\
\text { tradisional } & \left(S a^{\prime} O\right)\end{array}$ & $\begin{array}{l}\text { a. Bentuk atap dikonotasi sebagai metafora } \\
\text { dari bentuk mirip perahu } \\
\text { b. Simbol kewibawaan dari mosalaki } \\
\text { (ketua adat) } \\
\text { c. Penggamabaran dari tubuh manusia } \\
\text { yaitu kepala yang dihubungkan dengan } \\
\text { dunia atas }\end{array}$ \\
\hline $\begin{array}{l}\text { Bagian } \\
\text { Tengah }\end{array}$ & One & 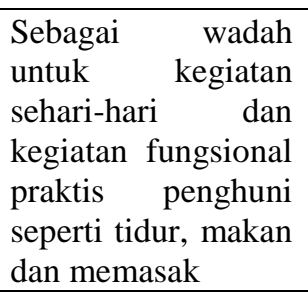 & $\begin{array}{l}\text { a. Wadah bagi asas-asas hidup manusia } \\
\text { untuk menciptakan kehidupan yang } \\
\text { harmonis } \\
\text { b. Rahim dari rumah tradisional ( } \mathrm{Sa} \text { 'o) } \\
\text { c. Penggambaran dari badan manusia yang } \\
\text { dihubungkan dengan dunia tengah }\end{array}$ \\
\hline $\begin{array}{l}\text { Bagian } \\
\text { Bawah }\end{array}$ & Lewu & $\begin{array}{l}\text { Kontruksi } \\
\text { penopang/penahan } \\
\text { struktur rumah } \\
\text { trdisional ( } \mathrm{Sa} \text { 'o) }\end{array}$ & $\begin{array}{l}\text { a. Bagian yang dianggap terendah dan } \\
\text { kotor. } \\
\text { b. Wadah bagi hewan seperti babi dan } \\
\text { ayam yang digunakan sebagai upacara } \\
\text { adat }\end{array}$ \\
\hline
\end{tabular}

Tabel 1. Pembagian rumah tradisional ( $s a^{\prime} o$ ) secara vertikal Sumber: Hasil Analisis, 2016 


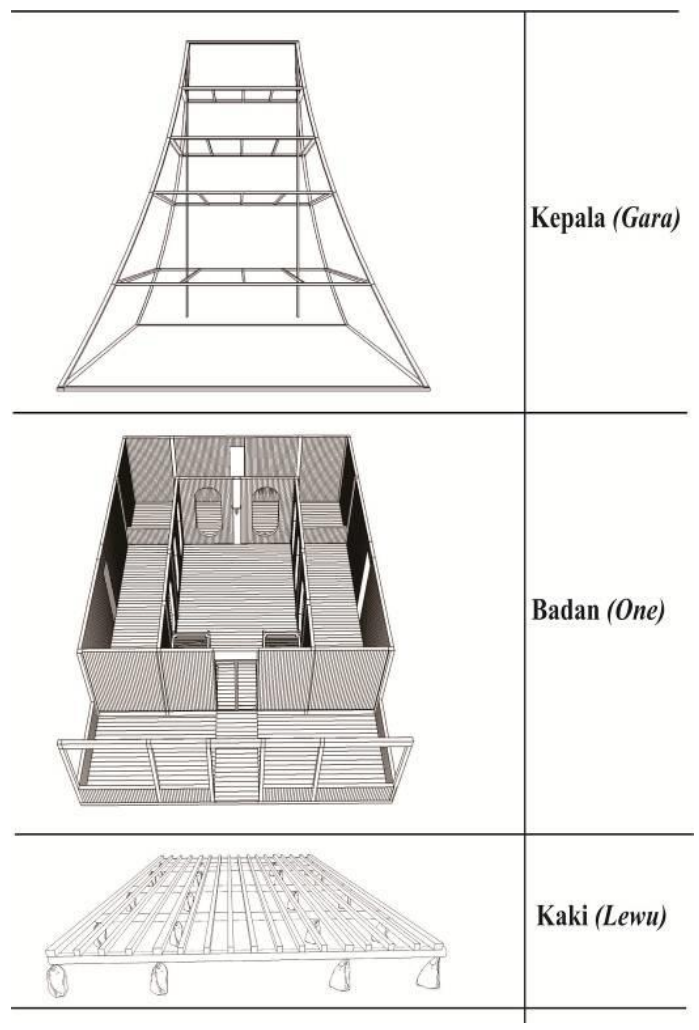

Gambar 5. Kosmologi vertikal pada rumah tradisional (sa'o) desa adat Saga

Sumber: Hasil Analisis, 2016

Secara konsep horizontal merupakan nilai kemanusiaan yang mengarah hubungan sosial antara manusia dan mengacu pada cardinal point (titik pusat). Pembagian fungsi pada sistem horizontal pada rumah tradisional ( $\mathrm{Sa}$ 'o) dibagi dalam empat fungsi utama yaitu bagian depan (tenda) merupakan area publik yang bersifat sosial untuk menerima tamu laki-laki dan tempat bersantai. Bagian tengah atau dalam (koja ndawa) merupakan area utama yang merupakan posisi yang sangat penting karena menjadi pusat pada $\mathrm{Sa}$ 'o, tempat berkumpul dan ruang bersama. Bagian samping kiri dan kanan terdapat dhembi yang dijadikan ruang istirahat perempuan, ruang bersifat privat. Bagian belakang (lulu) atau ruang istirahat lakilaki atau gudang tergantung dari ukuran
Sa'o. Bagian depan disebut tenda merupakan ruang yang berada bagian yang paling depan dari $S a$ 'o sebelum kita masuk ke dalam Sa'o. Ruang tenda secara fungsi digunakan sebagai area menerima tamu laki-laki dan ruang santai, ruang makan tamu saat upacara adat. Bagian tengah disebut koja ndawa. Ruang koja ndawa berfungsi sebagai sebagai tempat berkumpul keluarga di dalam $S a$ 'o dan juga sebagai tempat untuk makan bersama. Ruang koja ndawa juga disebut rahim dari $S a$ 'o. Bagian samping disebut dhembi. Ruang dhembi terdiri atas dua ruang yaitu dhembi kiri dan kanan. Ruang dhembi berfungsi sebagai ruang istirahat perempuan. Bagian belakang disebut lulu. Ruang lulu berfungsi sebagai ruang istirahat laki-laki dan gudang.

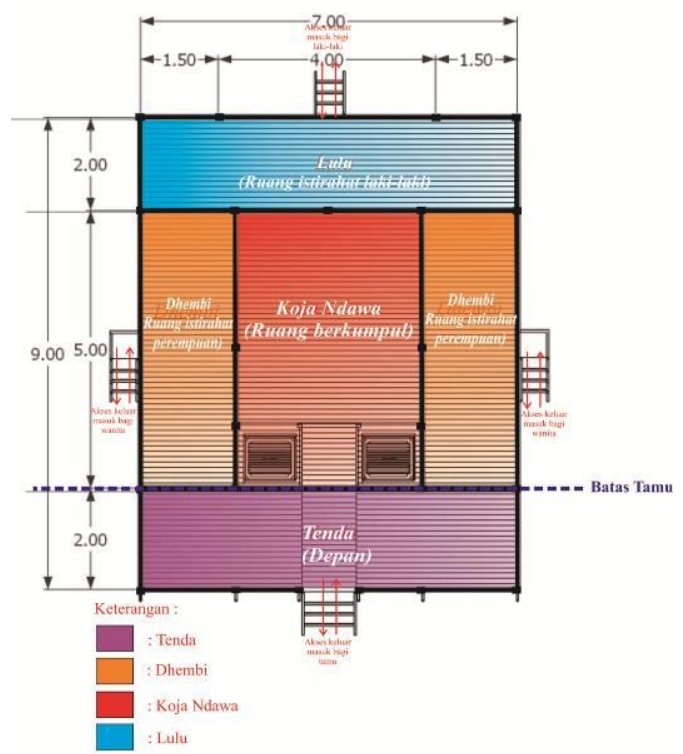

Gambar 6. Pembagian ruang pada rumah tradisional (sa'o) desa adat Saga

Sumber: Hasil Analisis, 2016

Pandangan kosmologi ruang pada rumah tradisional Desa Adat Saga secara horizontal dilukiskan dengan ibu terbaring. Metafora $\mathrm{Sa}$ 'o diklasifikasikan 
sebagai metafora sebagai seorang ibu memberikan penjelasan tentang keberadaan nilai-nilai perempuan yang sangat dijunjung tinggi. Sosok seorang seorang ibu terlihat jelas pada ukiran pintu (pene ria) masuk $\mathrm{Sa}$ 'o yakini ukiran payudara seorang wanita yang melambangkan kehidupan manusia dan sebuah papan yang melintang dibawah peneria yaitu koba leke yang melambangkan perkembangan manusia. Hakekatnya rumah tradisional Saga merupakan inti dari kesuburan dan kelahiran.

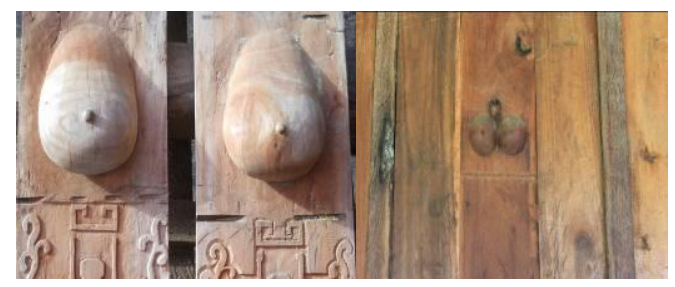

Gambar 7. Musu susu dan koba leke Sumber: Dokumentasi Pribadi, 2016

Posisi kepala ibu di bagian lulu (ruang istirahat laki-laki), kedua kaki yang menggujur kedepan berada pada bagian tenda (ruang istirahat atau menerima tamu), kedua tangan yang mereba berada pada ruang dhembi kanan dan kiri, rahim atau puse berada pada ruang koja ndawa. Lulu merupakan ruang istirahat laki-laki yang secara konotasi merupakan ulu (kepala) dalam perihal ini laki-laki merupakan kepala keluarga atau kepala rumah tangga. Kedua kaki yang menggujur ke depan dikonotasikan setiap orang yang ingin masuk ke rumah tradisional $\left(\mathrm{Sa} \mathrm{a}^{\prime} \mathrm{)}\right.$ ) dijamu pada ruang tenda dan kedua kaki tersebut berhenti pada ruang tenda. Dhembi kiri dan kanan merupakan ruang istirahat perempuan dikonotasikan kedua tangan yang sedang mereba sedangkan koja ndawa dijadikan rahim ibu, dikonotasikan sebagai area berkumpul dan ruang bersama.

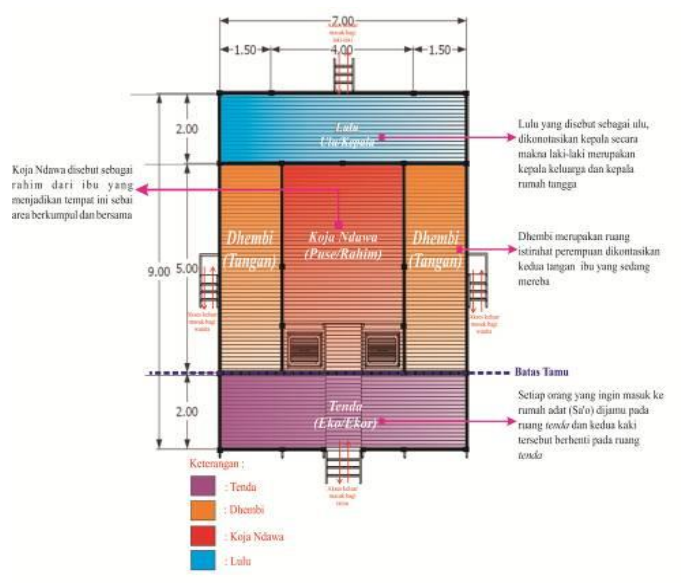

Gambar 8. Kosmologi horizontal pada rumah tradisional (sa'o) desa adat Saga

Sumber: Hasil Analisis, 2016

\begin{tabular}{|c|c|c|l|l|}
\hline Sa'o & Ruang & Wujud & \multicolumn{1}{|c|}{ Fungsi } & \multicolumn{1}{|c|}{ Konotasi/Simbolik } \\
\hline $\begin{array}{c}\text { Bagian } \\
\text { Depan }\end{array}$ & Tenda & Eko & $\begin{array}{l}\text { Ruang santai dan } \\
\text { ruang menerima. }\end{array}$ & $\begin{array}{l}\text { Setiap orang yang ingin masuk } \\
\text { ke rumah tradisional }(S a \text { 'o) } \\
\text { dijamu pada ruang tenda dan } \\
\text { kedua kaki tersebut berhenti } \\
\text { pada ruang tenda. }\end{array}$ \\
\hline $\begin{array}{c}\text { Bagian } \\
\text { Samping }\end{array}$ & Dhembi & $\begin{array}{c}\text { Dhembi } \\
\text { kandan } \\
\text { kiri }\end{array}$ & $\begin{array}{l}\text { Ruang } \\
\text { perempuan. }\end{array}$ & $\begin{array}{l}\text { kedua tangan yang sedang } \\
\text { mereba. }\end{array}$ \\
\hline $\begin{array}{c}\text { Bagian } \\
\text { Tengah }\end{array}$ & Koja & Puse & $\begin{array}{l}\text { Area berkumpul dan } \\
\text { ruang bersama. }\end{array}$ & $\begin{array}{l}\text { Rahim Sa'o } \\
\text { Bagian } \\
\text { Bawah }\end{array}$ \\
\hline
\end{tabular}




\begin{tabular}{|l|l|l|l|l|}
\hline & & $\begin{array}{l}\text { konotasi merupakan } \\
\text { ruang belakang. }\end{array}$ & $\begin{array}{l}\text { keluarga atau kepala rumah } \\
\text { tangga }\end{array}$ \\
\hline
\end{tabular}

Tabel 2. Pembagian rumah tradisional (sa’o) secara horizontal

Sumber: Hasisl Analisis, 2016
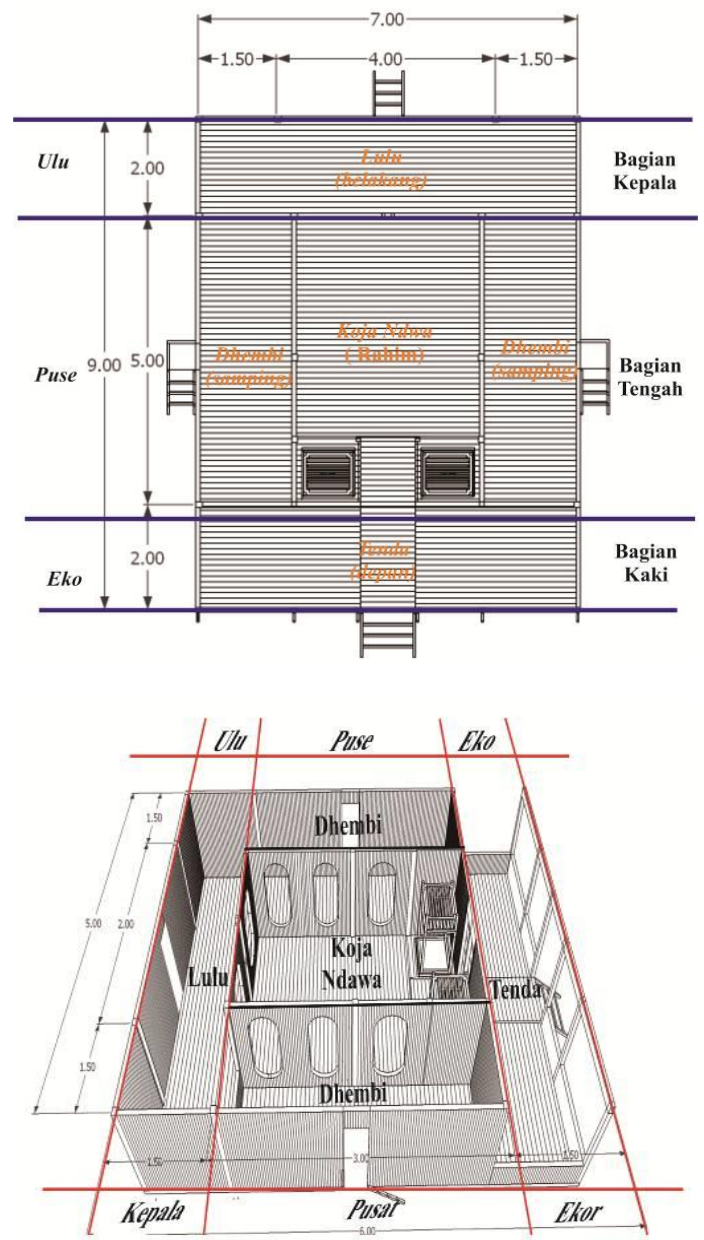

Gambar 9. Pembagian ruang secara horizontal pada rumah tradisional (sa'o) desa adat Saga

Sumber: Hasil Analisis, 2016

Berdasarkan analisis sistem vertikal dan horizontal pada permukiman Desa Adat Saga dipengaruhi dengan nilai kepercayaan. Kosmologi secara vertikal lebih kepada perwujudan hubungan manusia dengan ketuhanan yang menujukan tingkat hirarki pada $\mathrm{Sa}^{\prime} \mathrm{o}$ yang dibagi dalam tiga tingkatan yaitu lewu (kaki), one (badan) dan gara (kepala). Kosmologi secara horizontal lebih diwujudkan dalam hubungan sosial kemanusiaan/kemasyarakatan yang dilukiskan metafora dari seorang ibu yang sedang terbaring yang membagi dalam empat (4) bagian yaitu lulu (ulu/kepala), koja ndawa (puse/tengah), dhembi (rebahan tangan) dan tenda (eko/menggujur kedua kaki). Metafora seorang ibu memberikan penjelasan tentang keberadaan perempuan yang sangat dijunjung tinggi (hasil wawancara A.M Mako salah satu keturunan mosalaki (ketua adat) Desa Adat Saga, April, 2016).

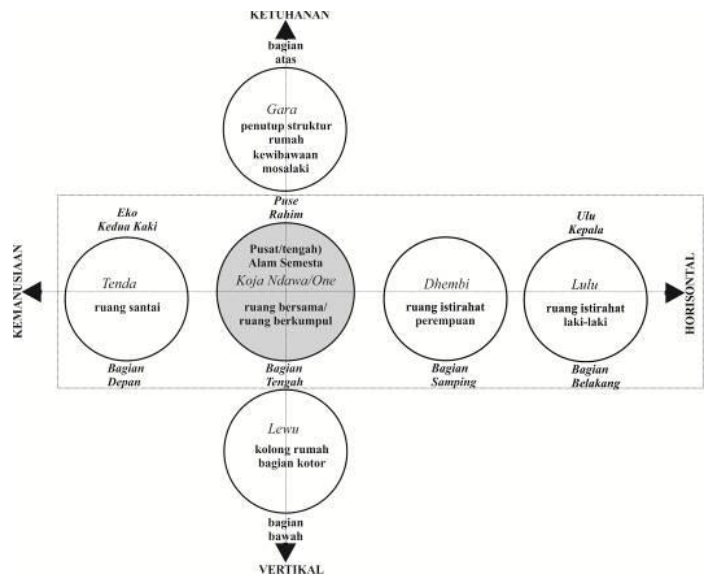

Gambar 10. Kosmologi secara vertikal dan horizontal pada rumah tradisional ( $s a^{\prime} o$ ) desa adat Saga

Sumber: Hasil Analisis, 2016

Pandangan kosmologi dalam konsep vertikal dianggap sebagai bentuk makrokosmos dari alam semesta yaitu dunia bawah (bawah tanah), dunia tengah (alam semesta), dan dunia atas (langit). Pembagian konsep vertikal juga dianalogikan sebagai manusia yang 
memiliki kaki, badan dan kepala. Konsep horizontal mengarah pada hubungan sosial antara manusia dan mengacu pada satu titik pusat (cardinal point).

Tata letak pembagian vertikal dan horizontal pada Arsitektur Ende Lio pada Desa Adat Saga menyerupai salah satu rumah_tradisional di NTT salah satunya pada arsitektur tradisional Sumba. Adat dan kepercayaan yang mereka pegang yaitu " Marapu” yaitu sistem kepercayaan masyarakat yang mempercayai arwah nenek moyang atau leluhur yang telah meninggal tetap hidup ditengah-tengah mereka dan meminta perlindungan dan berkah (Topan, 2005). Sistem kepercayaan Marapu membagi dunia menjadi tiga bagian yaitu dunia atas sebagai tempat para dewa dan arwah leluhur, dunia tengah sebagai tempat kehidupan manusia dan dunia bawah sebagai tempat hewan. Pembagian diwujudkan ruang rumah secara vertikal yaitu uma deta (dunia atas), ruang dalam rumah (uma bei) sebagai kehidupan dan kolong (kali kambunga) sebagai tempat hewan (Hariyanto, et.al 2012). Pembagian ruang secara horizontal pada rumah tradisional Sumba sangat jelas dengan pola yang memisahkan area pria dan wanita dengan pusat rumah pada tempat perapian ditengah (rapu) (Mross dalam Hariyanto et.al, 2012).

Jika dilhat dari sistem kepercayaan yang dianut oleh masih-masing permukiman adat Saga dan permukiman adat Sumba ditarik kesimpulan rumah tradisional Saga di Kabupaten Ende dan rumah tradisional Sumba Barat di Pulau Sumba, secara umum memiliki kesamaan dengan pembagian ruang secara vertikal dibagi atas tiga bagian yaitu dunia atas, dunia tengah dan dunia bawah sedangkan secara horizontal pembagian ruangnya berpusat pada satu titik yaitu pada ruang tengah.

\section{Kesimpulan}

Kosmologi ruang vertikal dan horizontal pada rumah tradisional ( $\mathrm{Sa}$ 'o) Desa Adat didasari atas kepercayaan Du'a Ngga'e. Berdasarkan kepercayaan masyarakat Saga yang membagi dunia menjadi tiga yaitu dunia atas, dunia tengah dan dunia bawah sehingga penggambaran rumah tradisional ( $\mathrm{Sa}$ 'o) menyerupai bentuk manusia yaitu atap (dunia atas), dunia tengah (badan rumah) dan dunia bawah (kaki rumah).

Pandangan kosmologis ruang pada rumah tradisional Saga secara vertikal rumah tradisional Saga dibedakan menjadi tiga bagian yaitu adalah lewu, one dan gara sebagaimana menyebut posisi bagian tubuh manusia. Gara adalah kepala, one merupakan badan dan lewu adalah kaki. Apabila menyebut ruang atap, dinding dan tiang lantai panggung, maka ruang atap sebagai gara, dinding sebagai one dan kolong disebut lewu. Pandangan kosmologi ruang rumah tradisional Desa Adat Saga secara horizontal dilukiskan dengan ibu terbaring. Posisi kepala ibu di bagian lulu (ruang istirahat laki-laki), kedua kaki yang menggujur kedepan berada pada bagian tenda (ruang istirahat atau menerima tamu), kedua tangan yang mereba berada pada ruang dhembi kanan dan kiri, rahim atau puse berada pada ruang koja ndawa. 


\section{Daftar Pustaka}

Basrowi \& Suwandi. (2008). Memahami Penelitian Kualitatif. Rineka Cipta, Jakarta.

Hariyanto, A. D, et.al. (2012). Hubungan Ruang, Bentuk dan Makna pada Arsitektur Tradisional Sumba Barat. LPPM, UKP.

Kustedja, S. Antariksa, \& Salura, P. (2012). Kosmologi Media Interprestasi Makna Pada Arsitektur Tionghoa Tradisional. Jurnal Sosioeknologi, 11 (27).

Koentjaraningrat. (1974). Kebudayaan Mentalitas dan Pembangunan. Gramedia Pustaka Utama, Jakarta.

Lake, Reginaldo Christophori. (2015), "Wologai, Eksotisme Vernakular di Kaki Gunung Lepembusu", Yayasan Gita Kasih, Kupang.

Lake, Reginaldo Christophori. (2015). Budaya Tektonika Wologai Ende, Nusa Tenggara Timur Sebuah Seni Berkonstruksi Rumah Adat Desa Wologai Tengah, Kecamatan Detusoko, Warisan Leluhur Wawo - Ata Lio di Bawah Kaki Gunung Lepembusu. ATRIUM - Jurnal Arsitektur.

https://doi.org/10.21460/atvm.2016. 12.15 .

Mashuri. (2012). Perwujudan Kosmologi Pada Bangunan Rumah tradisional Toraja. LANTING Journal of Architecture, 1 (1):1-10.

Mangunwijaya, Y. B. Wastu, Citra. (1988). Pengantar ke Ilmu Budaya Bentuk Arsitektur Sendi sendi Filsafatnya Beserta Contoh-Contoh Praktis. Jakarta.

Mbete, A. et.al. (2004). Khazanah Budaya Lio Ende. Pustaka Larasan. Dinas Pendidikan dan Kebudayaan Kabupaten Ende.
Pangarsa, G. W. (2006). Merah Putih Arsitektur Nusantara. Andi Offset, Yogyakarta.

Spradley, J. P. (1997). Metode Etnografi terjemahan buku The Etnograpic Interview. Diterjemahkan oleh Misbah Zulfa Elizabeth. Tiara Wacana Yogya, Yogyakarta.

Suwandi dan Basrowi. (2008). Memahami Penelitian Kualitatif. PT. Rineka Cipta, Jakarta.

Topan, M. A. (2005). Morfologi Arsitektur Sumba. Jurnal Penelitian dan Karya Ilmiah Lemlit USAKTI 17. 
Jurnal Teknik Arsitektur ARTEKS, Volume. I, Nomor 2, Juni 2017 ISSN 2541-0598 